\title{
Management of concomitant coronary artery disease and aortic valve stenosis in the era of transcatheter aortic valve treatment
}

\author{
Stefano Cangemi ${ }^{1,2}$, Cristina Aurigemma ${ }^{1}$, Enrico Romagnoli ${ }^{1}$, Francesco Bianchini ${ }^{1,2}$, Piergiorgio Bruno ${ }^{1,2}$, \\ Marialisa Nesta ${ }^{1}$, Francesco Burzotta ${ }^{1,2}$, Carlo Trani ${ }^{1,2}$ \\ 'Department of Cardiovascular Medicine, Fondazione Policlinico Universitario A. Gemelli IRCCS, Rome 00168, Italy. \\ ${ }^{2}$ Department of Cardiovascular and Pulmonary Sciences, Catholic University of the Sacred Heart, Rome 00168, Italy.
}

Correspondence to: Prof. Francesco Burzotta, Department of Cardiovascular Medicine, Fondazione Policlinico Universitario A Gemelli IRCCS, L.go A. Gemelli 1, Rome 00168, Italy. E-mail: francesco.burzotta@unicatt.it

\begin{abstract}
How to cite this article: Cangemi S, Aurigemma C, Romagnoli E, Bianchini F, Bruno P, Nesta M, Burzotta F, Trani C. Management of concomitant coronary artery disease and aortic valve stenosis in the era of transcatheter aortic valve treatment. Mini-invasive Surg 2022;6:3. https://dx.doi.org/10.20517/2574-1225.2021.99
\end{abstract}

Received: 24 Aug 2021 First Decision: 11 Oct 2021 Revised: 27 Oct 2021 Accepted: 30 Nov 2021 Published: 6 Jan 2022

Academic Editors: Andrea Scotti, Giulio Belli Copy Editor: Yue-Yue Zhang Production Editor: Yue-Yue Zhang

\begin{abstract}
Severe calcific aortic stenosis (AS) and coronary artery disease (CAD) have common risk factors and are frequently encountered in the same patient in clinical practice. CAD has been reported in $\geq 50 \%$ of AS patients undergoing both surgical treatment and transcatheter aortic valve implantation (TAVI). In the last two decades, TAVI has been established as a less invasive alternative to surgery. Recently, more and more young and low surgical risk patients undergo TAVI. Despite the high prevalence of CAD in patients treated with TAVI, the management strategy of concomitant CAD in these patients remains an area of considerable uncertainty. This review provides an updated overview of the current knowledge about this topic and offers points for reflection about the best approach to use.
\end{abstract}

Keywords: Severe aortic stenosis, coronary artery disease, transcatheter aortic valve implantation

\section{INTRODUCTION}

Aortic valve stenosis (AS) is the most common valvular heart disease undergoing surgical treatment in developed countries ${ }^{[1]}$. Its prevalence increases exponentially with age, and up to $5 \%$ of people between 75

The Author(s) 2022. Open Access This article is licensed under a Creative Commons Attribution 4.0 International License (https://creativecommons.org/licenses/by/4.0/), which permits unrestricted use, sharing adaptation, distribution and reproduction in any medium or format, for any purpose, even commercially, as long as you give appropriate credit to the original author(s) and the source, provide a link to the Creative Commons license, and indicate if changes were made. 
and 86 of age have a moderate to severe form ${ }^{[2]}$. There is evidence that risk factors for aortic stenosis are similar to those for atherosclerotic disease ${ }^{[2,3]}$. Consequently, coronary artery disease (CAD) is often concurrently found in patients presenting with severe AS, and its incidence increases with the age ${ }^{[4]}$. Surgical aortic valve replacement (SAVR) was the first treatment to increase survival in patients with severe aortic stenosis and was the only one for decades. Transcatheter aortic valve implantation (TAVI) has revolutionized the treatment of severe aortic stenosis, allowing many high-risk patients to receive a treatment, which increases life expectancy. The prevalence of CAD in TAVI candidates is estimated to be around $40 \%-75 \%{ }^{[5]}$. In randomized clinical trials comparing TAVI to SAVR, there was a progressive reduction in the prevalence of CAD in TAVI candidates in parallel with lower surgical risk and younger age ${ }^{[6-11]}$. With the progressive reduction of age and surgical risk of patients who are candidates for TAVI, optimal management of concomitant coronary artery disease becomes crucial. Important unresolved questions are if, how, and when to treat coexisting coronary artery disease.

\section{PROGNOSTIC IMPACT OF CORONARY ARTERY DISEASE IN PATIENTS WITH AORTIC STENOSIS CANDIDATES FOR TREATMENT}

It is still unknown whether CAD can be considered a detrimental factor or just an innocent bystander marker of high risk. This is probably due to the heterogeneity of the definition of CAD and its composite endpoints, the small sample size, the limited use of physiological assessment through fractional flow reserve (FFR), the uncertain completeness of revascularization or coronary stenosis severity, and the limited followup duration of studies [Supplementary Table 1]. One of the main limitations of these studies is that they do not correctly differentiate patients for severity of coronary artery disease and different types of revascularization. Severity of CAD and its presentation could better stratify patient prognosis. In support of this thesis, other features have been variably associated with prognosis: a clinical presentation with acute coronary syndrome $(\mathrm{ACS})^{[12]}$, CAD severity ${ }^{[13]}$, and incomplete revascularization with a high residual SYNTAX SCORE ${ }^{[13]}$. Moreover, in a single-center Polish registry, the presence of chronic total occlusion was associated with higher all-cause mortality rate in patients undergoing TAVI, but these patients had a more frequent history of stroke and chronic obstructive pulmonary disease $\mathrm{e}^{[14]}$. Different meta-analyses on this topic showed conflicting results regarding the association between CAD and clinical outcomes post$\operatorname{TAVR}^{[15-17]}$.

\section{TREATMENT OF CORONARY ARTERY DISEASE IN PATIENTS WITH AORTIC STENOSIS CANDIDATES FOR TREATMENT}

The main question to be answered in each TAVI procedural planning is whether patients with established CAD should undergo coronary revascularization. Several observational and retrospective studies comparing TAVI vs. TAVI and percutaneous coronary intervention (PCI) in patients with CAD did not find a significant difference in terms of mortality [Supplementary Table 2]. This lack of evidence could also be related to the reasons mentioned above. Another limitation of these retrospective studies is the selection bias of candidates for revascularization: patients with more severe CAD are revascularized, while those with stenosis in distal vessels tend to be treated with medical therapy. In several studies, the presence of CAD increased the procedural risk of $\mathrm{SAVR}^{[18]}$. Moreover, a higher mortality was found in concomitant coronary artery bypass graft $(\mathrm{CABG})+\mathrm{SAVR}$ than in SAVR alone ${ }^{[19]}$. In all randomized trials $\mathrm{s}^{[-11]}$ comparing TAVI to SAVR, PCI in addition to TAVI was less frequent compared to SAVR + CABG [Figure 1]. This trend reflects the approach recommended by the current guidelines ${ }^{[0,21]}$ that suggest revascularization of the proximal coronary stenosis in TAVI candidates and recommend CABG in patients with a primary indication for SAVR. These recommendations are based mainly on retrospective studies and registries data. The ACTIVATION trial ${ }^{[22]}$ was the first randomized trial to compare routine PCI and medical treatment in patients affected by severe AS and CAD undergoing to TAVI. This study showed no difference in the 


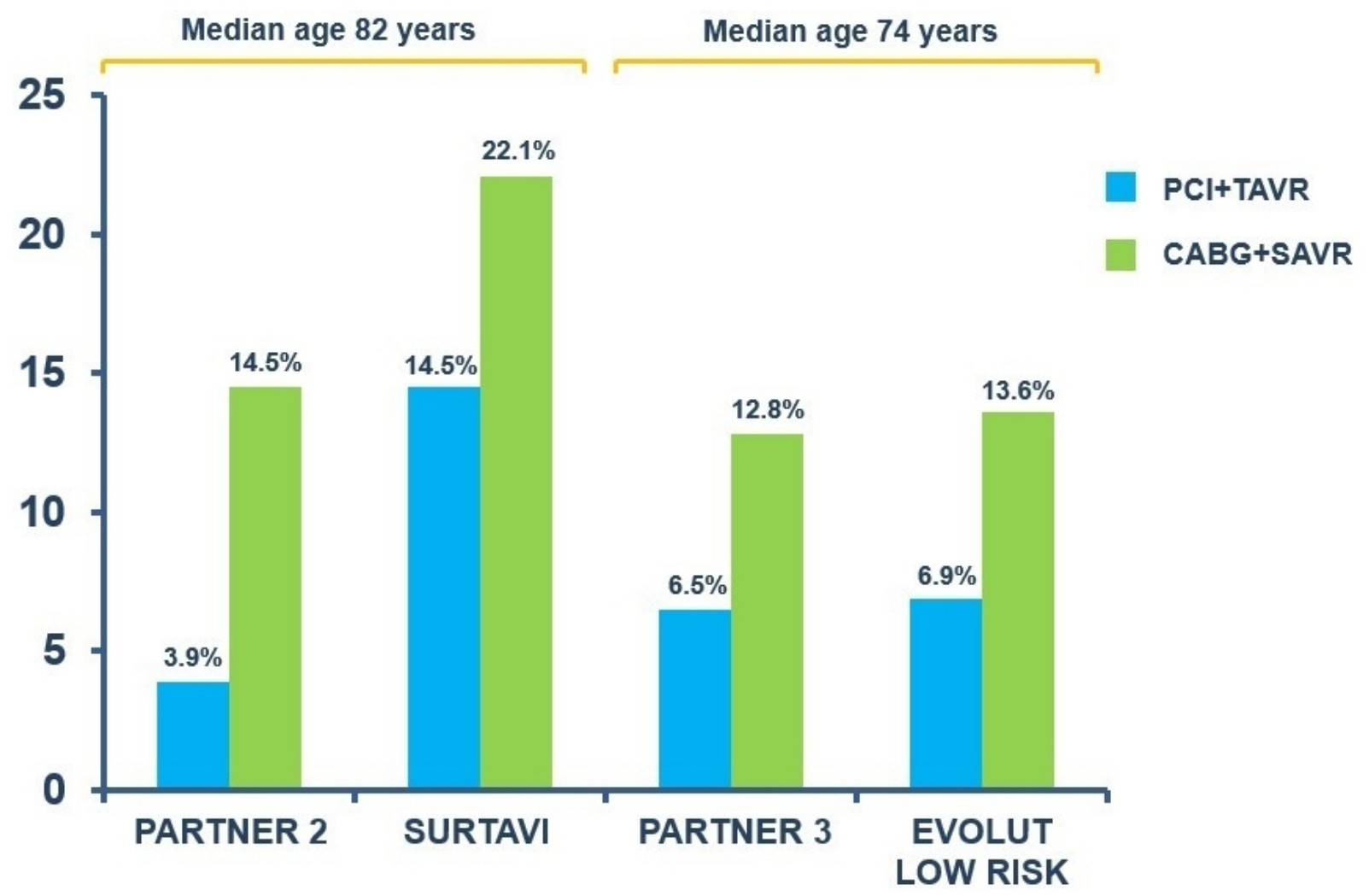

Figure 1. Rate of coronary revascularization in patients undergoing aortic valve treatment.

primary endpoints of death and re-hospitalization at one-year follow-up ${ }^{[23]}$ between the two groups. Moreover, at one year follow-up, there was no evidence of a difference in the rates of stroke, myocardial infarction, or acute kidney injury, but there was a higher rate of any bleed in the PCI $\operatorname{arm}^{[23]}$. The SURTAVI trial ${ }^{[24]}$ was the only randomized study to compare both percutaneous (TAVI + PCI) and surgical (SAVR + $\mathrm{CABG}$ ) treatment strategies in patients with severe AS and no-complex CAD. At two-year follow-up, there was no significant difference in the primary endpoint (all-cause mortality or stroke). Similar results were obtained by the Observant study ${ }^{[25]}$ (an Italian registry 2010-2012). In addition, a recent meta-analysis showed that a percutaneous strategy was comparable to a surgical one in patients with severe AS and $\mathrm{CAD}^{[26]}$.

\section{FUNCTIONAL GUIDED REVASCULARIZATION OF CONCOMITANT CORONARY ARTERY DISEASE IN PATIENTS WITH SEVERE AORTIC STENOSIS}

Functional guided revascularization with FFR has been shown to have numerous advantages compared to angiography-guided revascularization ${ }^{[27,28]}$ and medical therapy alone ${ }^{[29]}$. However, even though the European Society of Cardiology guidelines on chronic coronary syndrome ${ }^{[30]}$ recommend the use of functional assessment in patients with intermediate coronary artery stenosis, the European guidelines for the management of valvular heart disease ${ }^{[20]}$ only recommend angiographic evaluation. The American guidelines on valvulopathies ${ }^{[21]}$ consider the use of invasive coronary physiology in patients who are candidates for TAVI safe. The discordance between European and American guidelines ${ }^{[20]}$ is related to the absence of randomized controlled trials on clinical outcome and the low reliability of physiological indices in severe aortic stenosis. In patients with severe aortic stenosis, there is a significant increase in resting coronary flow due to the hypertrophy of the left ventricle ${ }^{[31-35]}$. The augmented resting coronary flow cannot 
further increase during physical exercise (thus explaining discrepancy angina) and when vasodilators are administered during FFR assessment. Pesarini et al. ${ }^{[35]}$, measuring FFR before and after TAVI, revealed that after prosthesis implantation negative baseline values became even more negative and positive ones became even more positive. Only $6 \%$ of lesions exhibited such a variation that resulted in a change of indication to treat. Despite the risk of FFR to underestimate some intermediate coronary lesions, in a single-center Italian registry ${ }^{[36]}$, FFR-guided revascularization was superior to angio-guided revascularization at two-year followup. It has been shown that coronary flow during the wave-free period of diastole remains unchanged after $\mathrm{TAVI}^{[37]}$. Instantaneous wave-free ratio (iFR), an index independent of vasodilatation, is calculated during this period and does not vary significantly before and after $\mathrm{TAVI}^{[37]}$. However, in patients with severe AS, there is an increased resting coronary blood flow, which could affect currently validated thresholds for iFR. Yamanaka et al ${ }^{[38]}$ compared iFR and FFR with myocardial perfusion scintigraphy in patients affected by CAD and severe AS. They showed a good correlation between FFR/iFR and perfusion scintigraphy in identifying myocardial ischemia. Moreover, an optimal cut-off of 0.82 for the iFR was identified to indicate an FFR $<0.75$ and myocardial ischemia on perfusion scintigraphy. The optimal cut-off of 0.82 for iFR in this setting of patients has been confirmed in other studies ${ }^{[39]}$. Recently, revascularization based on a "hybrid iFR-FFR" strategy has been proposed ${ }^{[40]}$. This strategy uses iFR as the primary choice to evaluate coronary stenosis and FFR evaluation for iFR values between 0.83 and $0.93^{[40]}$. The ongoing trials FAITAVI (Functional Assessment in TAVI), NOTION-3 (Revascularization in Patients Undergoing Transcatheter Aortic Valve Implantation), and TAVI-PET (Correlation of FFR and iFR With Cardiac PET Perfusion in Patients With Severe Aortic Valve Stenosis) will provide information to comprehend the role of FFR in this group of patients.

\section{THE OPTIMAL TIMING OF REVASCULARIZATION}

American guidelines ${ }^{[21]}$ recommend PCI before TAVI in the case of left main disease and significant proximal CAD. Instead, European guidelines ${ }^{[20]}$ do not recommend specific timing for coronary revascularization but suggest basing a decision on the clinical presentation, coronary anatomy, and extent of myocardial at risk. While performing PCI before TAVI reduces any ischemic events in the case of periprocedural complications and avoids difficult coronary engagement after implantation of the prosthesis, performing TAVI before PCI allows evaluating symptoms and hemodynamic significance of coronary lesions after the resolution of the aortic stenosis [Table 1]. Severe aortic stenosis was initially considered a contraindication for PCI. Instead, Goel et al. ${ }^{[41]}$ showed that this was feasible without an increase in mortality. A recent multicenter study highlighted that PCI before TAVI is currently performed successfully in most cases even in multivessel disease, left main disease, and calcific stenosis ${ }^{[42]}$. In the same study, the two-year rate of target vessel failure was low ${ }^{[22]}$. Regarding the disadvantages of performing PCI before TAVI, there is an increased risk of acute kidney injury, bleeding, and vascular complications ${ }^{[24,43,44]}$. Therefore, PCI before TAVI should be performed in the case of complex coronary stenosis with large myocardial area at risk, acute coronary syndromes, and even in the case of difficult coronary re-access after prosthesis implantation. With the improvement of techniques and experience of the operators, routinely performing PCI and TAVI in the same session has been proven to be safe and reduce hospitalization length $^{[45]}$ [Figure 2]. According to the literature, PBAV (percutaneous balloon aortic valvuloplasty) and PCI can be safely performed during the same procedure ${ }^{[4,47]}$. This approach can be used as a bridge to TAVI in patients with temporary TAVI contraindication. Small case series have shown the possibility of using Impella as an assistance during PBAV or PCI procedures in patients with severe aortic stenosis ${ }^{[8,49]}$.

The strategy of performing PCI after TAVI is a recent approach [Figure 3]. The revascularization of coronary disease was an inclusion criterion of the first trial due to the fear of ischemic events during the procedure and the lack of knowledge regarding the possibility of selective cannulate coronary arteries ostia 
Table 1. Timing of $\mathrm{PCl}$ in relation to TAVI

\begin{tabular}{|c|c|c|c|}
\hline & Advantages & Disadvantages & Preferred clinical scenario \\
\hline $\begin{array}{l}\text { Staged pre- } \\
\text { TAVI PCI }\end{array}$ & $\begin{array}{l}\text { Easier access to coronary arteries } \\
\text { Improve coronary flow, preventing } \\
\text { myocardial ischemia during } \\
\text { ventricular pacing }\end{array}$ & $\begin{array}{l}\text { Risk of acute decompensation during } \mathrm{PCl} \\
\text { Left main and right coronary artery ostial lesions } \\
\text { require special consideration because an implanted } \\
\text { valve can crush the stent frame } \\
\text { Increase vascular and bleeding complications due to } \\
\text { dual antiplatelet therapy }\end{array}$ & $\begin{array}{l}\text { Acute coronary syndrome } \\
\text { Severe left main stem lesions } \\
\text { and proximal coronary lesions } \\
\text { Complex coronary artery } \\
\text { lesions } \\
\text { Anatomical consideration } \\
\text { (type of-valve, valve-in-valve } \\
\text { procedure) }\end{array}$ \\
\hline $\begin{array}{l}\text { Staged post- } \\
\text { TAVI PCI }\end{array}$ & $\begin{array}{l}\text { Improve hemodynamic before } \mathrm{PCI} \\
\text { More accurate assessment of the } \\
\text { functional severity of CAD }\end{array}$ & $\begin{array}{l}\text { Risk of ischemia during TAVI } \\
\text { Cannulation of coronary artery and performing } \mathrm{PCI} \\
\text { may be more challenging }\end{array}$ & $\begin{array}{l}\text { Intermediate coronary artery } \\
\text { lesions }\end{array}$ \\
\hline $\begin{array}{l}\mathrm{PCl} \text { and } \\
\text { concomitant } \\
\text { TAVI }\end{array}$ & $\begin{array}{l}\text { Reduction of vascular complications } \\
\text { Reduce costs of hospitalizations } \\
\text { No delays in case of rescue/bail-out } \\
\text { strategies if needed }\end{array}$ & $\begin{array}{l}\text { Increase volume of contrast } \\
\text { Higher radiation dose } \\
\text { Longer duration of the procedure }\end{array}$ & $\begin{array}{l}\text { Normal kidney function } \\
\text { Simple coronary artery } \\
\text { stenosis }\end{array}$ \\
\hline
\end{tabular}

CAD: Coronary artery disease; PCl: percutaneous coronary intervention; TAVI: transcatheter aortic valve implantation.
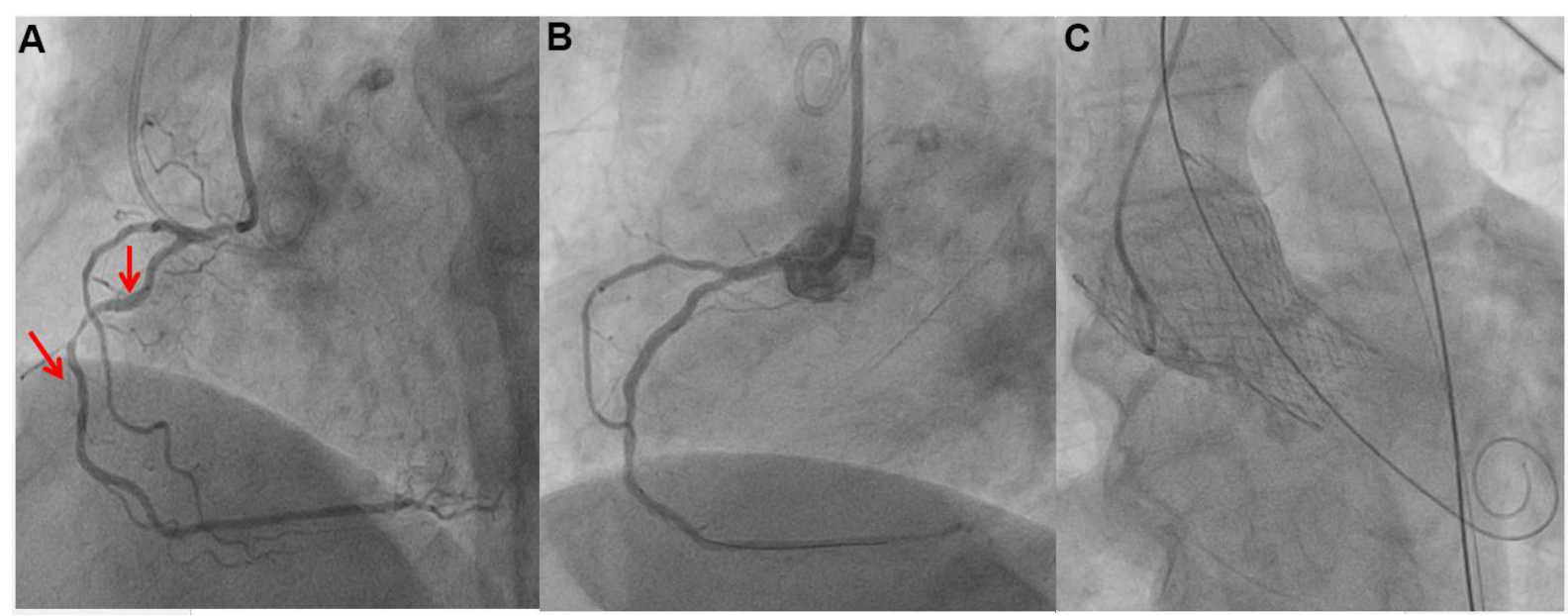

Figure 2. A concomitant myocardial revascularization and transcatheter aortic valve implantation (TAVI). The aortography performed during TAVI procedure showed a double stenosis of right coronary artery confirmed by selective angiography and not revealed by computed tomography scan (A). The coronary artery stenosis was very tight; therefore, the percutaneous treatment was performed before the TAVI (B). After the percutaneous coronary intervention ( $\mathrm{PCl}$ ), a self-expandable valve was implanted (C).

after TAVI. The major challenge of performing PCI in TAVI patients is selective cannulation of coronary ostia. This is an increasingly important problem given the progressive younger age of candidates for TAVI. A single-center study ${ }^{[50]}$ identified that $5.3 \%$ of TAVR recipients underwent coronary angiography during a follow-up of about three years. The authors attributed this low incidence to two possible causes: a Heart Team-based pre-TAVR revascularization and a possible reduced recourse to coronary angiography in the case of ACS due to the numerous comorbidities of the patients. The main factors that influence engagement of coronary ostia in patients with TAVI are divided into three groups: anatomical, related to the prosthesis, and procedural ${ }^{[51]}$. Generally, greater height of the coronary arteries and augmented width of valsalva sinuses are associated with easier coronary ostia engagement. In fact, coronary ostia are not covered by valve skirt, thus it is not difficult to cannulate the ostium ${ }^{[51,52]}$. All studies that evaluated the coronary access in patients with TAVI demonstrated greater difficulty with Evolut than Sapien prosthese ${ }^{[51,53,54]}$. The reasons are to be found in the different conformation and size of the two main types of valve prostheses currently used $^{[51]}$. The self-expanding valves (Evolut and Portico prostheses) are taller than balloon-expandable valves (Sapien prostheses) and extend beyond coronary ostia. Hence, if the neo-commissure of prosthesis is 


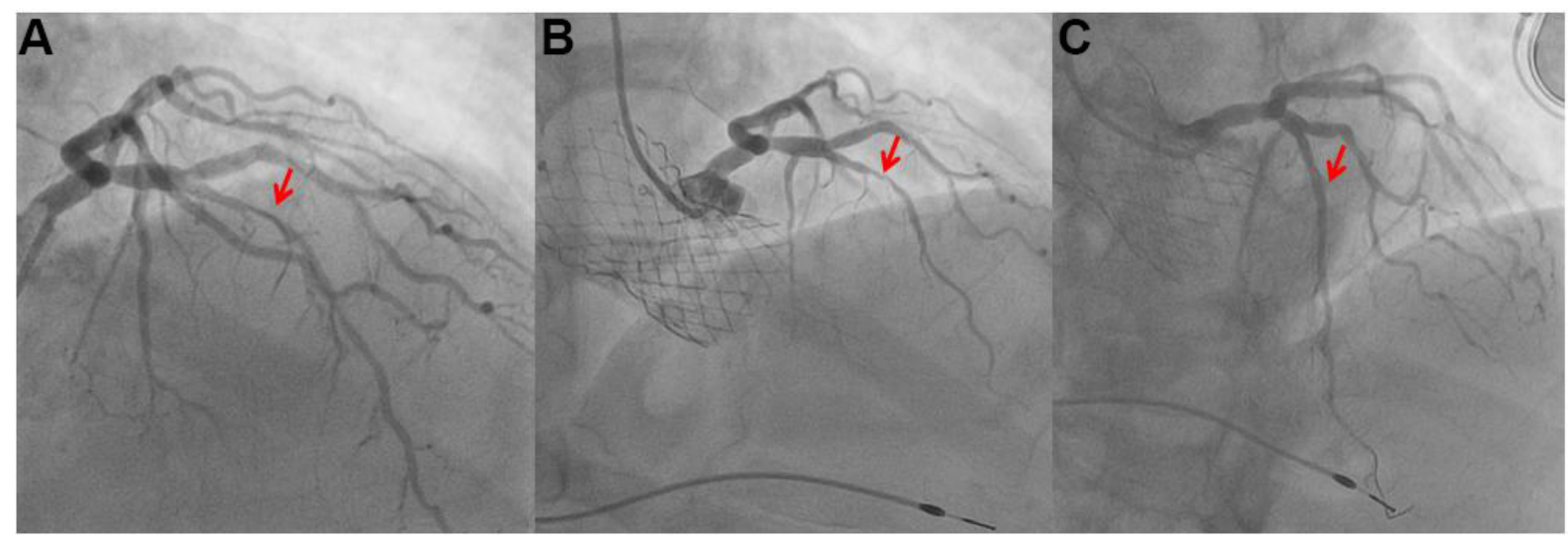

Figure 3. A staged post transcatheter aortic valve implantation (TAVI) myocardial revascularization. The coronary angiography showed a stenosis of the left anterior descending artery in the middle tract ( $A$ ). The patient was admitted because of pulmonary edema due to severe aortic stenosis. The coronary stenosis is not a sub-occlusive stenosis, therefore we decided to performed TAVI (B) and after one month a percutaneous treatment of the coronary stenosis (C).

oriented in front of coronary ostium it could hinder selective coronary cannulation. Moreover, Sapien prostheses have wider dimensions of the stent frame cells in the upper row which help selective coronary cannulation $^{[1,54]}$. Instead, procedural factors ${ }^{[3,55-57]}$ are high prosthesis implantation and commissural orientation of transcatheter aortic valve. The RE-ACCESS study ${ }^{[53]}$, a single-center prospective registry in which coronary angiography was routinely performed after TAVI, found that Evolut prosthesis, higher prosthesis-sinus of Valsalva relation, and low TAVI implantation depth were predictors of unsuccessful coronary cannulation. The ALIGN TAVR study ${ }^{[58]}$ showed that orienting the Evolut delivery catheter with the flush port positioned at 3 o'clock and tracking the Evolut hat marker at the outer curve of the thoracic aorta reduced the incidence of severe coronary artery overlap from $38 \%$ to $24 \%$. Tagliari et al. ${ }^{[59]}$ performed an experiment using 3D models of the aorta showing a neo-commissural alignment technique with Portico prosthesis. The recent COMALIGN study ${ }^{[60]}$ showed a more effective and patient-specific technique to achieve TAVI commissural alignment. This technique uses a patient-specific fluoroscopic projection in which the right and left coronary cusps (RCC/LCC) overlap. In this patient-specific fluoroscopic projection, the RCC/LCC commissure is directed to the right of the fluoroscopic image. The operator should use fluoroscopic markers that are specific for every device (Evolut, Acurate Neo, and Portico) and should orient one of the THV (transcatheter heart valve) commissures to the right of the screen in the RCC/LCC cusp overlap view. In this study, less than mild commissural misalignment was reached in $88 \%$ of patients.

Previous studies ${ }^{[57,58]}$ have evidenced that there is still no technique that guarantees to reduce commissural misalignment using Sapiens valves, but the low stent frame profile and the wide cells of the top row of the SAPIEN 3 prosthesis makes commissural alignment less relevant for coronary artery access. Besides commissural orientation of transcatheter aortic valve, the height of prosthesis implantation is another procedural factor influencing coronary cannulation after TAVI. Although one study ${ }^{[57]}$ estimated an approximately $10 \%$ incidence of unfavorable anatomy to cannulation in patients with Sapien valve (prosthesis frame above and commissural suture post in front of a coronary ostium), the SOURCE-3 trial ${ }^{[6]]}$ showed an excellent rate of selective coronary engagement and successful percutaneous coronary intervention in these patients. Cannulation of coronary ostia in patients with TAVI often requires the use of special techniques and catheters described in the literature ${ }^{[51,62,63]}$. In patients who have undergone SAVR, it is easier to perform coronary angiography because native leaflets are removed and surgical prosthesis is aligned to native commissures. At two years of follow-up, Ochiai et al. ${ }^{[64]}$ demonstrated that there is no difference in terms of outcomes as long as timing of PCI in TAVI candidates is tailored on a single patient 
by the Heart Team. It should be noted that, in all patients who had to implant self-expanding valve, the Heart Team always chose to perform PCI before TAVI ${ }^{[64]}$. According to the current studies, the best approach is to customize revascularization timing considering clinical characteristics, type of transcatheter aortic valve chosen, and complexity of CAD. A recent multicenter registry found that unplanned PCI after TAVR is rare and its incidence declines over time after TAVR ${ }^{[65]}$. Moreover, in this study ${ }^{[66]}$, the main indication to PCI was acute coronary syndrome in the first two years after TAVR. Multicenter registries ${ }^{[65-67]}$ showed that coronary angiography and PCI in TAVI patients affected by acute coronary syndrome is usually successful but coronary ostia cannulation failure was associated with poorer outcomes. Although a difficult access to the coronaries after TAVR is a great concern, it may be even more difficult to engage the coronary ostia after TAVR-in-TAVR. Commissural alignment is not the only factor to be considered in this particular setting. Nai Fovino et al. ${ }^{[68]}$ evidenced that female sex, reduced sinotubular junction diameter, implantation of supra-annular prosthesis, and reduced left coronary cannulation height are independent predictors of unfavorable coronary access after TAVR-in-TAVR.

\section{HYBRID APPROACHES}

In very high surgical risk patients with severe $A S$ and $C A D$, not eligible for traditional percutaneous therapy, the use of off-pump coronary artery bypass (OPCAB) and TAVI has been proposed. OPCAB is a technique of surgical coronary revascularization without the use of cardiopulmonary bypass. Minimally invasive direct $\mathrm{CABG}$ (MIDCAB) is an even less invasive surgical technique used to treat a single vessel CAD (usually left anterior descending artery). Baumbach et al. ${ }^{[69]}$, in a single-center prospective registry, compared outcomes of patients undergoing TAVI + OP/MIDCAB with those undergoing TAVI + PCI and SAVR + CABG. TAVI ( $58 \%$ transapical and $42 \%$ transaortic) + OP/MIDCAB was associated with the highest mortality and rehospitalization rate compared to TAVI (mainly transfemoral) + PCI (staged approach) and SAVR + CABG. This worrying in-hospital mortality rate for TAVI + OP/MIDCAB patients (18\%) was likely due to the fact these patients were sicker and older compared to the SAVR + CABG ones; this procedure is more invasive than percutaneous treatments and probably requires a steeper learning curve. This mortality rate is comparable to the one previously reported for this particular hybrid procedure in a comparable patient population ${ }^{[7]}$, but in another population of fewer patients there were no in-hospital deaths ${ }^{[71]}$. This difference is probably in relation with the patient condition and the surgeon's skills. To reduce the complexity of the procedure, mortality, and complications, it has recently been proposed to perform first MIDCAB and in a subsequent hospitalization TAVI (staged approach) ${ }^{[72]}$ [Table 2].

The use of minimally invasive valve surgery and PCI has been proposed as an alternative approach to concomitant CABG + SAVR. The aim of this approach is to prevent a standard median sternotomy. In relation to timing, there are two types of approaches, "staged" and "concomitant". Santana et al. ${ }^{[73,74]}$ demonstrated that a strategy of performing PCI with a median of 30 days before a minimally invasive aortic valve replacement was a safe and effective approach which permitted to reduce complications and length of hospital stay. The problems associated with the staged approach are the need to discontinue anti-platelets therapy during the perioperative period or the high risk of bleeding if the intervention is performed under anti-platelets therapy. In addition, the development of TAVI and the inferiority of PCI in the case of complex coronary anatomy has reduced enthusiasm for this approach. Brinster et al. ${ }^{[75]}$, before the spread of hybrid operating rooms, demonstrated the feasibility of a same-day PCI approach followed by SAVR. George et al. ${ }^{[76]}$ described the possibility of performing in the hybrid room first PCI followed by valve surgery (11 patients of 20 underwent SAVR). After four years there, was only one event (a stroke during hospitalization) in the absence of in-hospital mortality. Outcomes were comparable to those of traditional surgery [Table 3]. 
Table 2. Features of the main study on the hybrid approach off-pump coronary artery bypass and TAVI

\begin{tabular}{|c|c|c|c|c|c|c|c|c|}
\hline & $\begin{array}{l}\text { Number of } \\
\text { patients }\end{array}$ & Surgical rik score & $\begin{array}{l}\text { TAVI } \\
\text { approaches }\end{array}$ & Revescularization characteristics & Complications & $\begin{array}{l}\text { In-hospital } \\
\text { mortality }\end{array}$ & $\begin{array}{l}30 \text { days } \\
\text { mortality }\end{array}$ & $\begin{array}{l}\text { Long term } \\
\text { survival rate }\end{array}$ \\
\hline Baumbach et al. ${ }^{[69]}$ & 50 & $36.4 \pm 22.4$ (Euroscore 1 ) & $\begin{array}{l}\text { Tao (21) } \\
\text { TA (29) }\end{array}$ & $\begin{array}{l}\text { MIDCAB via left antero-lateral } \\
\text { minithoracotomy in the case of single-vessel } \\
\text { LAD or LCX artery disease; } \\
\text { OPCAB via median sternotomy in the case of } \\
\text { multi-vessel complex disease }\end{array}$ & $\begin{array}{l}\text { AKI stage II/III (5) } \\
\text { Re-thoracotomy (5) } \\
\text { Pericardial tamponade (1) } \\
\text { Stroke (1) } \\
\text { Periprocedural myocardial } \\
\text { infarction (1) }\end{array}$ & $9(18 \%)$ & $8(16 \%)$ & $\begin{array}{l}65.5 \% \text { at } 12 \\
\text { months }\end{array}$ \\
\hline Ahad et al. ${ }^{[70]}$ & 70 & $\begin{array}{l}35.9 \pm 21.9 \text { (Logistic } \\
\text { Euroscore) }\end{array}$ & $\begin{array}{l}\text { Tao (28) } \\
\text { TA (42) }\end{array}$ & $\begin{array}{l}\text { MIDCAB }(36 ; 51.4 \%) \\
\text { OPCAB (32; 45.7\%) } \\
\text { LIMA (66) } \\
\text { RIMA (21) } \\
\text { Vein (7) } \\
\text { Radial artery (2) }\end{array}$ & $\begin{array}{l}\text { AKI stage II/III (6) } \\
\text { Re-thoracotomy (6) } \\
\text { Pericardial tamponade (1) } \\
\text { Stroke (1) } \\
\text { Periprocedural myocardial } \\
\text { infarction (1) }\end{array}$ & $14(20 \%)$ & $10(14.3 \%)$ & $\begin{array}{l}74.4 \% \text { at } 12 \\
\text { months } \\
68.4 \% \text { at } 24 \\
\text { months }\end{array}$ \\
\hline Mayr et al. ${ }^{[71]}$ & 20 & $\begin{array}{l}16.1(9.3-28.1) \text { (Logistic } \\
\text { Euroscore }\end{array}$ & $\begin{array}{l}\text { Tao (9) } \\
\text { TA (5) } \\
\operatorname{TF}(5) \\
\text { TSC (1) }\end{array}$ & $\begin{array}{l}\text { OPCAB (6) } \\
\text { MIDCAB (14) } \\
\text { LIMA (17) } \\
\text { RIMA (6) } \\
\text { Complete revascularization (75) }\end{array}$ & $\begin{array}{l}\text { AKI stage II/III (2) } \\
\text { Re-thoracotomy (1) } \\
\text { Pericardial tamponade (1) } \\
\text { Stroke (0) } \\
\text { Periprocedural myocardial } \\
\text { infarction (0) }\end{array}$ & 0 & 0 & $\begin{array}{l}75 \% \text { at } 42 \\
\text { months }\end{array}$ \\
\hline Pirelli et al. ${ }^{[72]}$ & 6 & $8 \pm 3.3$ (STS-score) & $\begin{array}{l}\text { TF (4) } \\
\text { TA (1) } \\
\text { Transinnominate } \\
\text { (1) }\end{array}$ & $\begin{array}{l}\text { MIDCAB ( } 6) \\
\text { Preceded by } P C I \text { and BAV in } 3 \text { cases }\end{array}$ & $\begin{array}{l}\text { Complete heart block (1) } \\
\text { No neurological events or } \\
\text { major vascular } \\
\text { complications }\end{array}$ & 0 & 0 & $\begin{array}{l}100 \% \text { at } 12 \\
\text { months }\end{array}$ \\
\hline Zubarevich et al. ${ }^{[77]}$ & 10 & $\begin{array}{l}\text { Mean logistic Euroscore } \\
(26.5 \% \pm 12.3 \%) \text {, mean STS } \\
\text { score }(6.04 \% \pm 1.6 \%)\end{array}$ & Tao (10) & $\begin{array}{l}\text { OPCAB (10) } \\
\text { Complete revascularisation (7) } \\
\text { LIMA LAD (9) LIMA D1 (1) } \\
\text { Planned PCI (3) }\end{array}$ & $\begin{array}{l}\text { Acute kidney injury (2) } \\
\text { Rethoracotomy }(1) \\
\text { Pericardial effusion requiring } \\
\text { thoracotomy }(1) \\
\text { Reintubation } 1(10 \%) \\
\text { Septic shock } 1(10 \%)\end{array}$ & $1(10 \%)$ & $1(10 \%)$ & Missing data \\
\hline
\end{tabular}

AKI: Acute kidney injury; BAV: balloon aortic valvuloplasty; D1: first diagonal; LAD: left anterior descending artery; LCX: left circumflex artery; LIMA: left internal mammary artery; MICS-OPCAB: minimally invasive cardiac surgery coronary artery bypass; MIDCAB. minimally invasive direct CABG. OPCAB. off-pump coronary artery bypass; PCl: percutaneous coronary interventions; RIMA: right internal mammary artery; STS: Society of Thoracic Surgeons; TA: trans-apical; TAO: trans-aortic; TAVI: transcatheter aortic valve implantation; TCr: transcarotid; TF: trans-femoral; TSC: trans-subclavian.

\section{CONCLUSION}

Coronary artery disease is a common finding in patients with degenerative aortic valve stenosis with a prevalence estimated around 40\%-75\%. The presence of CAD alone did not affect short-term mortality, while severe CAD was conversely associated with higher one-year mortality. Therefore, important unresolved questions are if, how, and when to treat coexisting CAD. According to current evidence, complete myocardial revascularization should no longer be considered an essential requirement for TAVI. The safety and efficacy of functional guided revascularization with FFR or iFR is under evaluation in on-going 
Table 3. Features of the main studies on hybrid approach, percutaneous coronary intervention, and surgical aortic valve replacement treatment

\begin{tabular}{|c|c|c|c|c|c|c|c|}
\hline & $\begin{array}{l}\text { Number } \\
\text { of } \\
\text { patients }\end{array}$ & $\begin{array}{l}\text { PCl to surgery } \\
\text { (Time) }\end{array}$ & $\begin{array}{l}\mathrm{PCl} \text { vessels } \\
\text { and type of } \\
\text { intervention }\end{array}$ & Valve & Type of surgery & Complications & $\begin{array}{l}\text { In-hospital } \\
\text { mortality }\end{array}$ \\
\hline Santana et al. ${ }^{[74]}$ & 123 & 39 days (median) & $\begin{array}{l}\text { LAD (48\%) } \\
\text { LAD prox }(27.6 \\
\%) \\
\text { LCX }(32.5 \%) \\
\text { RCA }(33.3 \%) \\
\text { RI }(0.8 \%) \\
\text { Diagonal }(5.7 \%) \\
\text { PCI } 121 \\
\text { POBA } 2\end{array}$ & SAVR (123) & $\begin{array}{l}\text { Right anterior } \\
\text { thoracotomy }\end{array}$ & $\begin{array}{l}\text { Blood transfusion } \\
41, \\
\text { Reoperation for } \\
\text { bleeding 1, } \\
\text { Stroke 1, } \\
\text { Dialysis } 2\end{array}$ & $\begin{array}{l}\text { 30-day } \\
\text { mortality } 2 \\
(1.6 \%)\end{array}$ \\
\hline Brinster et al..$^{[75]}$ & 18 & $\begin{array}{l}<1 \text { day } \\
(12 \text {, same day but } \\
\text { two stages) }\end{array}$ & $\begin{array}{l}\text { LAD (61\%) } \\
\text { LCX (27\%) } \\
\text { RCA (17\%) } \\
\text { PCI } 18 \\
\text { POBA } 0\end{array}$ & SAVR (18) & $\begin{array}{l}\text { Right anterior } \\
\text { thoracotomy }\end{array}$ & $\begin{array}{l}8 \text { blood } \\
\text { transfusions, } \\
1 \text { stroke }\end{array}$ & 1 \\
\hline George et al. ${ }^{[76]}$ & 26 & $\begin{array}{l}\text { Simultaneously } \\
\text { (one stage) }\end{array}$ & $\begin{array}{l}\text { Valve-PCl: } \\
\text { RCA }(25.7 \%) ; \\
\text { LCX }(29.1 \%) ; \\
\text { LM }(15.6 \%) \\
\text { LAD prox } \\
(10.6 \%) \\
\text { LAD mid distal } \\
(32.2 \%)\end{array}$ & $\begin{array}{l}\text { Reoperative } \\
\text { valve-PCl } \\
\text { patient (14); } \\
\text { Primary valve } \\
\text { surgery (12) of } \\
\text { these } \\
\text { SAVR (11) }\end{array}$ & $\begin{array}{l}\text { Primary valve } \\
\text { surgery: } \\
\text { Hemisternotomy } \\
\text { (2) } \\
\text { Sternotomy (10) } \\
\text { Reoperative valve } \\
\text { surgery: } \\
\text { Sternotomy (13) } \\
\text { Right thoracotomy } \\
\text { (1) }\end{array}$ & $\begin{array}{l}\text { Blood transfusion } \\
1, \\
\text { Reoperation for } \\
\text { bleeding } 1 \text {, } \\
\text { Stroke 1 }\end{array}$ & 0 \\
\hline
\end{tabular}

LAD: Left anterior descending; LCX: left circumflex; LM: left main; PCl: percutaneous intervention; POBA: plain old balloon angioplasty; RCA: right coronary artery; RI: ramus intermedius; SAVR: surgical aortic valve replacement ; SVG: saphenous vein grafts.

research. The timing of PCI in TAVI candidates should be established considering the complexity of the coronary anatomy, type of valve prosthesis, symptoms, and comorbidities of the patient. Furthermore, the progressive younger age of patient candidates for TAVI makes the possibility of re-accessing the coronary arteries increasingly important. Thus, further studies on increasing coronary re-access after TAVR and best timing of PCI in relation to TAVI are necessary. Hybrid procedures may be the best answer in some selected patients. The best management of this condition is paradigmatic of the modern cardiology approach that is founded on Heart Team decisions. Modern cardiology is evolving towards tailored therapies which need collaboration among medical specialties that were once divided.

\section{DECLARATIONS}

\section{Authors'contributions}

Conception and design: Cangemi S

Drafting the article: Cangemi $S$

Final approval of the version to be published: Bianchini F, Trani C

Analysis and interpretation: Romagnoli E, Bruno P

Data collection: Burzotta F, Nesta M

Critical revision of the article: Aurigemma C

\section{Availability of data and materials}

Not applicable. 


\section{Financial support and sponsorship}

None.

\section{Conflicts of interest}

Aurigemma C, Burzotta F, Trani C received speaker's fees from Abbott, Medtronic, and Abiomed. Other authors declared that there are no conflicts of interest.

\section{Ethical approval and consent to participate}

Not applicable.

\section{Consent for publication}

Not applicable.

\section{Copyright}

(c) The Author(s) 2022.

\section{REFERENCES}

1. Iung B, Delgado V, Rosenhek R, et al; EORP VHD II Investigators. Contemporary presentation and management of valvular heart disease: the Eurobservational research programme valvular heart disease II survey. Circulation 2019;140:1156-69. DOI PubMed

2. Stewart B, Siscovick D, Lind BK, et al. Clinical factors associated with calcific aortic valve disease fn1fn1. J Am Coll Cardiol 1997;29:630-4. DOI PubMed

3. Yan AT, Koh M, Chan KK, et al. Association between cardiovascular risk factors and aortic stenosis: the CANHEART aortic stenosis study. J Am Coll Cardiol 2017;69:1523-32. DOI PubMed

4. Iung B. Interface between valve disease and ischaemic heart disease. Heart 2000;84:347-52. DOI PubMed PMC

5. Auffret V, Lefevre T, Van Belle E, et al; FRANCE TAVI Investigators. Temporal trends in transcatheter aortic valve replacement in France: France 2 to France TAVI. J Am Coll Cardiol 2017;70:42-55. DOI PubMed

6. Makkar RR, Fontana GP, Jilaihawi H, et al; PARTNER Trial Investigators. Transcatheter aortic-valve replacement for inoperable severe aortic stenosis. N Engl J Med 2012;366:1696-704. DOI PubMed

7. Kodali SK, Williams MR, Smith CR, et al; PARTNER Trial Investigators. Two-year outcomes after transcatheter or surgical aorticvalve replacement. N Engl J Med 2012;366:1686-95. DOI PubMed

8. Reardon MJ, Van Mieghem NM, Popma JJ, et al; SURTAVI Investigators. Surgical or transcatheter aortic-valve replacement in intermediate-risk patients. N Engl J Med 2017;376:1321-31. DOI PubMed

9. Leon MB, Smith CR, Mack MJ, et al; PARTNER 2 Investigators. Transcatheter or surgical aortic-valve replacement in intermediaterisk patients. N Engl J Med 2016;374:1609-20. DOI PubMed

10. Mack MJ, Leon MB, Thourani VH, et al; PARTNER 3 Investigators. Transcatheter aortic-valve replacement with a balloonexpandable valve in low-risk patients. $N$ Engl J Med 2019;380:1695-705. DOI PubMed

11. Popma JJ, Deeb GM, Yakubov SJ, et al; Evolut Low Risk Trial Investigators. Transcatheter aortic-valve replacement with a selfexpanding valve in low-risk patients. N Engl J Med 2019;380:1706-15. DOI PubMed

12. Saia F, Palmerini T, Compagnone M, et al. Coronary artery disease and reasonably incomplete coronary revascularization in high-risk patients undergoing transcatheter aortic valve implantation. Catheter Cardiovasc Interv 2020;95:19-27. DOI PubMed

13. Witberg G, Regev E, Chen S, et al. The prognostic effects of coronary disease severity and completeness of revascularization on mortality in patients undergoing transcatheter aortic valve replacement. JACC Cardiovasc Interv 2017;10:1428-35. DOI PubMed

14. Kleczynski P, Dziewierz A, Bagienski M, et al. Impact of coronary artery disease burden on 12-month mortality of patients after transcatheter aortic valve implantation. J Interv Cardiol 2016;29:375-81. DOI PubMed

15. Kotronias RA, Kwok CS, George S, et al. Transcatheter aortic valve implantation with or without percutaneous coronary artery revascularization strategy: a systematic review and meta-analysis. J Am Heart Assoc 2017;6:e005960. DOI PubMed PMC

16. Witberg G, Zusman O, Codner P, Assali A, Kornowski R. Impact of coronary artery revascularization completeness on outcomes of patients with coronary artery disease undergoing transcatheter aortic valve replacement: a meta-analysis of studies using the residual SYNTAX score (Synergy Between PCI With Taxus and Cardiac Surgery). Circ Cardiovasc Interv 2018;11:e006000. DOI PubMed

17. D'Ascenzo F, Verardi R, Visconti M, et al. Independent impact of extent of coronary artery disease and percutaneous revascularisation on 30-day and one-year mortality after TAVI: a meta-analysis of adjusted observational results. EuroIntervention 2018;14:e1169-77. DOI PubMed

18. Tjang YS, van Hees Y, Körfer R, Grobbee DE, van der Heijden GJ. Predictors of mortality after aortic valve replacement. Eur J Cardiothorac Surg 2007;32:469-74. DOI PubMed

19. Fujita B, Ensminger S, Bauer T, et al; GARY Executive Board. Trends in practice and outcomes from 2011 to 2015 for surgical aortic valve replacement: an update from the German Aortic Valve Registry on 42776 patients. Eur J Cardiothorac Surg 2018;53:552-9. DOI PubMed 
20. Vahanian A, Beyersdorf F, Praz F, et al; ESC/EACTS Scientific Document Group, ESC Scientific Document Group. 2021 ESC/EACTS Guidelines for the management of valvular heart disease. Eur Heart $J$;2021:ehab395. DOI PubMed

21. Otto CM, Nishimura RA, Bonow RO, et al; Writing Committee Members. 2020 ACC/AHA Guideline for the management of patients with valvular heart disease: executive summary: a report of the American college of Cardiology/American Heart Association Joint Committee on clinical practice guidelines. J Am Coll Cardiol 2021;77:450-500. DOI PubMed

22. Khawaja MZ, Wang D, Pocock S, Redwood SR, Thomas MR. The percutaneous coronary intervention prior to transcatheter aortic valve implantation (ACTIVATION) trial: study protocol for a randomized controlled trial. Trials 2014;15:300. DOI PubMed PMC

23. Patterson T, Clayton T, Dodd M, et al; ACTIVATION Trial Investigators. ACTIVATION (PercutAneous Coronary inTervention prIor to transcatheter aortic VAlve implantaTION): a randomized clinical trial. JACC Cardiovasc Interv 2021;14:1965-74. DOI PubMed

24. Søndergaard L, Popma JJ, Reardon MJ, et al; SURTAVI Trial Investigators. Comparison of a complete percutaneous versus surgical approach to aortic valve replacement and revascularization in patients at intermediate surgical risk: results from the randomized SURTAVI trial. Circulation 2019. DOI PubMed

25. Barbanti M, Buccheri S, Capodanno D, et al; OBSERVANT Research Group. Transcatheter or surgical treatment of severe aortic stenosis and coronary artery disease: a comparative analysis from the Italian OBSERVANT study. Int J Cardiol 2018;270:102-6. DOI PubMed

26. Kotronias RA, Bray JH, Scarsini R, et al. Transcatheter aortic valve replacement and percutaneous coronary intervention versus surgical aortic valve replacement and coronary artery bypass grafting in patients with severe aortic stenosis and concomitant coronary artery disease: a systematic review and meta-analysis. Catheter Cardiovasc Interv 2020;96:1113-25. DOI PubMed

27. Barbato E, Toth GG, Johnson NP, et al. A prospective natural history study of coronary atherosclerosis using fractional flow reserve. $J$ Am Coll Cardiol 2016;68:2247-55. DOI PubMed

28. van Nunen LX, Zimmermann FM, Tonino PAL, et al. Fractional flow reserve versus angiography for guidance of PCI in patients with multivessel coronary artery disease (FAME): 5-year follow-up of a randomised controlled trial. Lancet 2015;386:1853-60. DOI PubMed

29. Fearon WF, Nishi T, De Bruyne B, et al; FAME 2 Trial Investigators. Clinical outcomes and cost-effectiveness of fractional flow reserve-guided percutaneous coronary intervention in patients with stable coronary artery disease: three-year follow-up of the FAME 2 trial (fractional flow reserve versus angiography for multivessel evaluation). Circulation 2018;137:480-7. DOI PubMed

30. Knuuti J, Wijns W, Saraste A, et al; ESC Scientific Document Group. 2019 ESC Guidelines for the diagnosis and management of chronic coronary syndromes. Eur Heart J 2020;41:407-77. DOI PubMed

31. Rajappan K, Rimoldi OE, Dutka DP, et al. Mechanisms of coronary microcirculatory dysfunction in patients with aortic stenosis and angiographically normal coronary arteries. Circulation 2002;105:470-6. DOI PubMed

32. Eberli FR, Ritter M, Schwitter J, et al. Coronary reserve in patients with aortic valve disease before and after successful aortic valve replacement. Eur Heart J 1991;12:127-38. DOI PubMed

33. Stoller M, Gloekler S, Zbinden R, et al. Left ventricular afterload reduction by transcatheter aortic valve implantation in severe aortic stenosis and its prompt effects on comprehensive coronary haemodynamics. EuroIntervention 2018;14:166-73. DOI PubMed

34. Scarsini R, De Maria GL, Di Gioia G, et al. The influence of aortic valve obstruction on the hyperemic intracoronary physiology: difference between resting Pd/Pa and FFR in aortic stenosis. J Cardiovasc Transl Res 2019;12:539-50. DOI PubMed

35. Pesarini G, Scarsini R, Zivelonghi C, et al. Functional assessment of coronary artery disease in patients undergoing transcatheter aortic valve implantation: influence of pressure overload on the evaluation of lesions severity. Circ Cardiovasc Interv 2016;9:e004088. DOI PubMed

36. Lunardi M, Scarsini R, Venturi G, et al. Physiological versus angiographic guidance for myocardial revascularization in patients undergoing transcatheter aortic valve implantation. J Am Heart Assoc 2019;8:e012618. DOI PubMed PMC

37. Ahmad Y, Götberg M, Cook C, et al. Coronary hemodynamics in patients with severe aortic stenosis and coronary artery disease undergoing transcatheter aortic valve replacement: implications for clinical indices of coronary stenosis severity. JACC Cardiovasc Interv 2018;11:2019-31. DOI PubMed PMC

38. Yamanaka F, Shishido K, Ochiai T, et al. Instantaneous wave-free ratio for the assessment of intermediate coronary artery stenosis in patients with severe aortic valve stenosis: comparison with myocardial perfusion scintigraphy. JACC Cardiovasc Interv 2018;11:203240. DOI PubMed

39. Scarsini R, Cantone R, Venturi G, et al. Correlation between intracoronary physiology and myocardial perfusion imaging in patients with severe aortic stenosis. Int J Cardiol 2019;292:162-5. DOI PubMed

40. Scarsini R, Pesarini G, Lunardi M, et al. Observations from a real-time, iFR-FFR "hybrid approach" in patients with severe aortic stenosis and coronary artery disease undergoing TAVI. Cardiovasc Revasc Med 2018;19:355-9. DOI PubMed

41. Goel SS, Agarwal S, Tuzcu EM, et al. Percutaneous coronary intervention in patients with severe aortic stenosis: implications for transcatheter aortic valve replacement. Circulation 2012;125:1005-13. DOI PubMed

42. Faroux L, Campelo-Parada F, Munoz-Garcia E, et al. Procedural characteristics and late outcomes of percutaneous coronary intervention in the workup pre-TAVR. JACC Cardiovasc Interv 2020;13:2601-13. DOI PubMed

43. van Rosendael PJ, van der Kley F, Kamperidis V, et al. Timing of staged percutaneous coronary intervention before transcatheter aortic valve implantation. Am J Cardiol 2015;115:1726-32. DOI PubMed

44. Venturi G, Pighi M, Pesarini G, et al. Contrast-induced acute kidney injury in patients undergoing TAVI compared with coronary interventions. J Am Heart Assoc 2020;9:e017194. DOI PubMed PMC

45. Barbanti M, Todaro D, Costa G, et al. Optimized screening of coronary artery disease with invasive coronary angiography and ad hoc percutaneous coronary intervention during transcatheter aortic valve replacement. Circ Cardiovasc Interv 2017;10:e005234. DOI 
PubMed

46. Ben-Dor I, Maluenda G, Looser PM, et al. Outcomes of concomitant percutaneous coronary intervention and balloon aortic valvuloplasty. Catheter Cardiovasc Interv 2013;82:E835-41. DOI PubMed

47. Daniec M, Sorysz D, Dziewierz A, et al. In-hospital and long-term outcomes of percutaneous balloon aortic valvuloplasty with concomitant percutaneous coronary intervention in patients with severe aortic stenosis. J Interv Cardiol 2018;31:60-7. DOI PubMed

48. Singh V, Mendirichaga R, Inglessis-Azuaje I, Palacios IF, O'Neill WW. The role of impella for hemodynamic support in patients with aortic stenosis. Curr Treat Options Cardiovasc Med 2018;20:44. DOI PubMed

49. Diaz Quintero L, Gajo E, Guerrero M, Feldman T, Levisay J. Balloon aortic valvuloplasty followed by impella®-assisted left main coronary artery percutaneous coronary intervention in patients with severe aortic stenosis as a bridge to transcatheter aortic valve replacement. Cardiovasc Revasc Med 2021;22:16-21. DOI PubMed

50. Nai Fovino L, Scotti A, Massussi M, et al. Incidence and feasibility of coronary access after transcatheter aortic valve replacement. Catheter Cardiovasc Interv 2020;96:E535-41. DOI PubMed

51. Yudi MB, Sharma SK, Tang GHL, Kini A. Coronary angiography and percutaneous coronary intervention after transcatheter aortic valve replacement. J Am Coll Cardiol 2018;71:1360-78. DOI PubMed

52. Ribeiro HB, Webb JG, Makkar RR, et al. Predictive factors, management, and clinical outcomes of coronary obstruction following transcatheter aortic valve implantation: insights from a large multicenter registry. J Am Coll Cardiol 2013;62:1552-62. DOI PubMed

53. Barbanti M, Costa G, Picci A, et al. Coronary cannulation after transcatheter aortic valve replacement: the RE-ACCESS study. JACC Cardiovasc Interv 2020;13:2542-55. DOI PubMed

54. Ochiai T, Chakravarty T, Yoon SH, et al. Coronary access after TAVR. JACC Cardiovasc Interv 2020;13:693-705. DOI PubMed

55. Katsanos S, Debonnaire P, van der Kley F, et al. Position of edwards SAPIEN transcatheter valve in the aortic root in relation with the coronary ostia: implications for percutaneous coronary interventions. Catheter Cardiovasc Interv 2015;85:480-7. DOI PubMed

56. Abdelghani M, Landt M, Traboulsi H, Becker B, Richardt G. Coronary access after TAVR with a self-expanding bioprosthesis: insights from computed tomography. JACC Cardiovasc Interv 2020;13:709-22. DOI PubMed

57. Rogers T, Greenspun BC, Weissman G, et al. Feasibility of coronary access and aortic valve reintervention in low-risk TAVR patients. JACC Cardiovasc Interv 2020;13:726-35. DOI PubMed

58. Tang GHL, Zaid S, Fuchs A, et al. Alignment of transcatheter aortic-valve neo-commissures (ALIGN TAVR): impact on final valve orientation and coronary artery overlap. JACC Cardiovasc Interv 2020;13:1030-42. DOI PubMed

59. Tagliari AP, Vicentini L, Zimmermann JM, et al. Transcatheter aortic valve neo-commissure alignment with the Portico system. EuroIntervention 2021;17:e152-5. DOI PubMed

60. Bieliauskas G, Wong I, Bajoras V, et al. Patient-specific implantation technique to obtain neo-commissural alignment with selfexpanding transcatheter aortic valves. JACC Cardiovasc Interv 2021;14:2097-108. DOI PubMed

61. Tarantini G, Nai Fovino L, Le Prince P, et al. Coronary access and percutaneous coronary intervention up to 3 years after transcatheter aortic valve implantation with a balloon-expandable valve. Circ Cardiovasc Interv 2020;13:e008972. DOI PubMed PMC

62. Khan M, Senguttuvan NB, Krishnamoorthy P, et al. Coronary angiography and percutaneous coronary intervention after transcatheter aortic valve replacement with medtronic self-expanding prosthesis: insights from correlations with computer tomography. Int J Cardiol 2020;317:18-24. DOI PubMed

63. Bharadwaj AS, Bhatheja S, Sharma SK, Kini AS. Utility of the guideliner catheter for percutaneous coronary interventions in patients with prior transcatheter aortic valve replacement. Catheter Cardiovasc Interv 2018;91:271-6. DOI PubMed

64. Ochiai T, Yoon SH, Flint N, et al. Timing and outcomes of percutaneous coronary intervention in patients who underwent transcatheter aortic valve implantation. Am J Cardiol 2020;125:1361-8. DOI PubMed

65. Stefanini GG, Cerrato E, Pivato CA, et al; REVIVAL Investigators. Unplanned percutaneous coronary revascularization after TAVR: a multicenter international registry. JACC Cardiovasc Interv 2021;14:198-207. DOI PubMed

66. Faroux L, Lhermusier T, Vincent F, et al. ST-segment elevation myocardial infarction following transcatheter aortic valve replacement. J Am Coll Cardiol 2021;77:2187-99. DOI PubMed

67. Kim WK, Pellegrini C, Ludwig S, et al. Feasibility of coronary access in patients with acute coronary syndrome and previous TAVR. JACC Cardiovasc Interv 2021;14:1578-90. DOI PubMed

68. Nai Fovino L, Scotti A, Massussi M, et al. Coronary angiography after transcatheter aortic valve replacement (TAVR) to evaluate the risk of coronary access impairment after TAVR-in-TAVR. J Am Heart Assoc 2020;9:e016446. DOI PubMed PMC

69. Baumbach H, Schairer ER, Wachter K, et al. Transcatheter aortic valve replacement- management of patients with significant coronary artery disease undergoing aortic valve interventions: surgical compared to catheter-based approaches in hybrid procedures. $B M C$ Cardiovasc Disord 2019;19:108. DOI PubMed PMC

70. Ahad S, Wachter K, Rustenbach C, et al. Concomitant therapy: off-pump coronary revascularization and transcatheter aortic valve implantation. Interact Cardiovasc Thorac Surg 2017;25:12-7. DOI PubMed

71. Mayr B, Firschke C, Erlebach M, et al. Transcatheter aortic valve implantation and off-pump coronary artery bypass surgery: an effective hybrid procedure in selected patients. Interact Cardiovasc Thorac Surg 2018;27:102-7. DOI PubMed

72. Pirelli L, Patel NC, Scheinerman JS, et al. Hybrid minimally invasive approach for combined obstructive coronary artery disease and severe aortic stenosis. Innovations (Phila) 2020;15:131-7. DOI PubMed

73. Santana O, Funk M, Zamora C, Escolar E, Lamas GA, Lamelas J. Staged percutaneous coronary intervention and minimally invasive valve surgery: results of a hybrid approach to concomitant coronary and valvular disease. J Thorac Cardiovasc Surg 2012;144:634-9. DOI PubMed

74. Santana O, Xydas S, Williams RF, et al. Outcomes of a hybrid approach of percutaneous coronary intervention followed by minimally 
invasive aortic valve replacement. J Thorac Dis 2017;9:S569-74. DOI PubMed PMC

75. Brinster DR, Byrne M, Rogers CD, et al. Effectiveness of same day percutaneous coronary intervention followed by minimally invasive aortic valve replacement for aortic stenosis and moderate coronary disease ("hybrid approach"). Am J Cardiol 2006;98:15013. DOI PubMed

76. George I, Nazif TM, Kalesan B, et al. Feasibility and early safety of single-stage hybrid coronary intervention and valvular cardiac surgery. Ann Thorac Surg 2015;99:2032-7. DOI PubMed

77. Zubarevich A, Zhigalov K, Szczechowicz M, et al. Simultaneous transaortic transcatheter aortic valve implantation and off-pump coronary artery bypass: an effective hybrid approach. J Card Surg 2021;36:1226-31. DOI PubMed 